\title{
PERAN YAYASAN KUNTUM DALAM PEMBERDAYAAN MASYARAKAT MUSLIMAH DI KAMPUNG WISATA BISNIS TEGALWARU CIAMPEA BOGOR
}

\author{
Bela Kurnia \\ STID AL-HADID, Surabaya \\ belakurnn22@gmail.com \\ Agus Susanto \\ STID AL-HADID, Surabaya \\ agussusanto@stidalhadid.ac.id
}

\begin{abstract}
The study aims to analyze roles of the agents of change in Islamic society development in Kampung Wisata Bisnis Tegalwaru Ciampea Bogor by Yayasan Kuantum. The literary study uses library research model. The study concludes that roles implemented by Yayasan Kuantum Indonesia as the agent of change are as follows: (1) Facilitative role, by actively becoming the subject which socializes ideas about KWBT to Tegalwaru citizens, committing deals of cooperation in stating the benefit share from the visit, and engaging them as parts of the KWBT programs' participants; (2) Educational roles, by awakening the awareness of Tegalwaru small enterprises to be willing to implement change in their own lives, delivering insights and trainings of entrepreneurship, delivering marketing training by using online medias; (3) Representative roles, by seeking the required resources, legalizing the establishment of programs, setting corporations with various external foundations, developing networks with people outside Tegalwaru, using social media roles, websites, television


broadcasts, and YouTube videos for the requirements of publication in KWBT and promoting the products of Tegalwaru small enterprises. (4) technical roles, by gathering internal and external potentials through KWBT programs, moreover, Yayasan Kuantum also conducts management to program implementation, and the financial management inside.

Keywords: Muslimah society development, Role of Yayasan Kuantum, Tegalwaru Ciampea Bogor Business Small Village.

\section{Pendahuluan}

Pada dasarnya Islam adalah agama pemberdayaan ${ }^{1}$, dalam pandangan Islam, pemberdayaan harus merupakan gerakan tanpa henti (berkelanjutan), hal ini selaras dengan paradigma Islam sendiri sebagai agama perubahan ${ }^{2}$. Semangat Islam akan kemandirian banyak banyak dijumpai pada ayat al-Qur'an maupun al-Hadist ${ }^{3}$. Secara terminologis pemberdayaan masyarakat Islam berarti menstransformasikan dan melembagakan semua segi ajaran Islam dalam kehidupan keluarga (usrah), kelompok sosial (jama'ab) dan masyarakat (ummah). ${ }^{4}$ Pemberdayaan masyarakat Islam merupakan usaha untuk mendorong keinginan, upaya, dan partisipasi masyarakat dalam melakukan perubahan. ${ }^{5}$

Dalam sebuah upaya pemberdayaan masyarakat, selain ada unsur komunitas yang akan diberdayakan, juga ada unsur agen perubahan atau pekerja sosial. Pekerja sosial adalah pihak yang menginisiasi adanya perubahan dalam suatu komunitas, secara umum fungsinya untuk membantu atau mendampingi masyarakat dalam memecahkan masalah sosial yang mereka miliki secara mandiri. ${ }^{6}$ Intervensi agen perubahan, menurut Indrawati dan Sukma Paramastuti dengan menyandarkan pada teori model intervensi Rothman dan Tropman ada tiga model: (1)

\footnotetext{
1 Al-Qurâ'an, 107: 103.

2 Nanih Machendrawaty, Agus Ahmad Safei, Pengembangan Masyarakat Islam - Dari Ideologi, Strategi, Sampai Tradisi (Bandung: Remaja Rosdakarya, 2001), 41.

${ }^{3}$ Ibid, 47.

${ }^{4}$ Ibid, 42.

5 Faizal dalam Wahanani Mawasti dan Tri Djoyo Budiono, Memberdayakan Masyarakat Islam Melalui Bank. Sampab: Strategi Komunikasi Stakeholder Bank Sampah Songolikoer dalam Inteleksia, Vol 01 (Surabaya: Jurnal Pengembngan Dakwah, 2020), 285.

6 Abu Huraerah, Pengorganisasian Dan Pengembangan Masyarakat, Model Dan Strategi Pembangunan Berbasis Kerakyatan (Bandung: Humaniara, 2011), 50.
} 
perencanaan sosial; (2) pengembangan masyarakat lokal; (3) aksi sosial ${ }^{7}$. Sedangkan soal peran agen perubahan, Jim Ife dan Frank Tesoriero dalam bukunya Community Development menyebutkan ada empat peran dan keterampilan yang harus dimiliki oleh agen perubahan sebagai pemberdaya masyarakat yaitu meliputi peran fasilitatif, peran edukasional, peran teknis, dan peran sebagai perwakilan komunitas. ${ }^{8} \mathrm{Jim}$ Iffe dan Frank Tesoriero menyatakan bahwa dalam satu aktivitas, seorang pekerja masyarakat sering berpenampilan dengan tiga wajah peran pada satu waktu. ${ }^{9}$

Salah satu program pemberdayaan masyarakat terkait peran agen perubahan di bidang ekonomi yang sukses memutus angka kemiskinan, adalah pemberdayaan ekonomi berbasis Kewirausahaan Sosial yang dilakukan oleh Ibu Tatiek Kancaniati dan Yayasan Kreativitas Usaha Unit Muslimah (Kuntum) di komunitas Muslimah desa Tegalwaru, Bogor. Secara umum, mayoritas warga desa Tegalwaru memiliki profesi sebagai petani dan wirausaha dengan berbagai jenis produk. Walaupun tersebar banyak jenis usaha rumahan di desa tersebut, namun warga desa Tegalwaru belum terlepas dari masalah ekonomi, dikarenakan pendidikan yang rendah, dan kurangnya pengetahuan mereka tentang pemasaran produk mengakibatkan para wirausaha yang ada kesulitan mengembangkan usahanya tersebut, banyak kemudian yang memilih menyerah dengan keadaan tersebut dan memutuskan untuk menjadi tenaga kerja diluar negeri atau buruh pabrik ke perkotaan, banyak juga anak-anak putus sekolah serta menikah di usia dini, kemudian menjadi ibu rumah tangga tanpa mempunyai keterampilan tertentu, menyebabkan tingkat kemiskinan masih tinggi di desa ini $^{10}$. Bahkan pada tahun 2009, desa Tegalwaru menjadi desa dengan pendapatan perkapita paling kecil se- Kabupaten Bogor. ${ }^{11}$

\footnotetext{
${ }^{7}$ Indrawati \& Sukma Paramastuti. "Intervensi Komunitas "Rifka Annisa" Yogyakarta Pada Perempuan Korban Kekerasan Dalam Rumah Tangga." INTELEKSLA-Jurnal Pengembangan Ilmu Dakwah 1.02 (2020): 187-211.

${ }^{8}$ Jim Ife dan Frank Tesoriero, Community Development diterjemahkan oleh Sastrawan Manurung, Nurul Yakin, M.Nursyahid, disunting oleh Saifudin Zuhri Qudsi (Yogyakarta : Pustaka Pelajar, 2008), 591.

${ }^{9} \mathrm{Ibid}, 556$.

${ }^{10}$ Gustyanita Pratiwi, "Tatiek Kancaniati: Perintis Kampoeng Wisata Bisnis Tegalwaru," $S W A, 3$ Februari, 2014, dalam https://swa.co.id/swa/headline/tatiek-kancaniati-perintis-kampoengwisata-bisnis-tegalwaru. (diakses pada tanggal 13 juli 2020).

11 Bryan Wicaksono, "Peran Yayasan Kreativitas Unit Muslimah (KUNTUM) Indonesia dalam Mengurangi Pengangguran Melalui Praktik. Kewirausahaan Sosial di Desa Tegal Waru, Bogor" (Skripsi Program Studi Kesejahteraan Sosial, Universitas Islam Negeri Syarif Hidayatullah, Jakarta, 2015).
} 
Ibu Tatiek Kancaniati yang merupakan warga asli desa Tegalwaru menyadari bahwa masalah tersebut harus dipecahkan. Ia mempunyai pandangan bahwa masyarakatnya, sebenarnya punya modal berupa kreativitas dari usahanya yang bisa dikembangkan lebih besar lagi, dan juga di desa Tegalwaru ada berbagai potensi alam yang mungkin bisa dimanfaatkan, pada tahun 2008 ia mendirikan sebuah Yayasan Kreativitas Usaha Unit Muslimah (Kuntum). Tahun 2009, Yayasan Kuntum mengajak beberapa pemilik usaha rumahan para wanita muslimah di desa Tegalwaru untuk bergabung bersama dalam rangka membuat desa Tegalwaru menjadi sebuah Kampung Wisata Bisnis Tegalwaru (KWBT). ${ }^{12}$ Di tahun 2013 omzet pendapatan mitra UKM Tegalwaru mencapai 2,2 miliar per bulannya. ${ }^{13}$ Selain adanya peningkatan omzet, keberadaan Kampung Wisata Tegalwaru juga berhasil menyerap tenaga kerja desa Tegalwaru, sehingga pengangguran pun berkurang, begitu juga angka kemiskinan yang awalnya per tahun 2010/2011 sebanyak 1005 rumah tangga miskin, berkurang menjadi 346 rumah tangga miskin pada tahun $2016 .^{14}$

Berdasarkan pemaparan di atas, fenomena peran Yayasan Kuantum Bogor dalam memberdayakan Komunitas Muslimah Kampung Wisata Tegalwaru sangat menarik untuk dikaji dari sudut pandang peranannya sebagai agent of change atau agen perubahan dalam pemberdayaan masyarakat Islam. Untuk itu, rumusan masalah yang dibahas dalam studi ini adalah "Bagaimanakah Peran Yayasan Kuantum di Komunitas Muslimah Kampung Wisata Bisnis Tegalwaru Ciampea Bogor pada Tahun 2009-2015?”. Sedangkan tujuannya adalah untuk menganalisis peranan yang dilakukan oleh Yayasan Kuntum di Komunitas Muslimah Kampung Wisata Bisnis Tegalwaru, CiampeaBogor pada tahun 2009 -2015. Adanya studi ini diharapkan memberikan referensi dalam praktik pemberdayaan masyarakat, terutama pada aspek peran-peran agen perubahan agar pemberdayaan masyarakat yang tengah dilakukan bisa turut ikut sukses.

Objek yang dikaji dalam studi ini adalah Yayasan Kuantum Bogor yang ditinjau dari pendekatan konsep peran agen perubahan pada pemberdayan masyarakat. Kajian terdahulu yang telah mengkaji tema

\footnotetext{
12 Ibid.

13 A. Syalaby Ichsan "Tegal Waru, Kampung Usaha Beromzet Rp 2,2 Miliar," Republika.co.id, 23 Juni, 2013, dalam https://m.republika.co.id/berita/ekonomi/bisnis/13/06/23/motvmg-tegal-warukampung-usaha-beromzet-22-miliar di akses 13 Juli, 2020).

14 Awalnya Desa Tertinggal, Kini Mampu Berdaya - Big Bang Show, video YouTube, 0:34 - 0:40, di unggah oleh "KOMPAS TV”, 5 Desember, 2016, dalam https://youtu.be/6DLCjMZV4rE.
} 
sejenis, diantaranya adalah Strategi Pemberdayaan Ekonomi oleh Yayasan Kreativitas Usaha Unit Muslimah (KUNTUM) Indonesia Melalui Pengembangan Usaha Kecil Menengah (UKM) di Desa Tegal Waru Ciampea Bogor oleh Ade Yunus. ${ }^{15}$ Kajian tersebut berfokus strategi pemberdayaan yang dilakukan oleh Yayasan Kuantum. Hasil dari kaijian itu bahwa Yayasan Kuntum dalam proses pemberdayaannya Yayasan Kuntum melakukannya dengan menggali potensi dan mengembangkanya dengan kemasan yang lebih baik dan menarik. Dalam penggalian potensi Yayasan Kuntum melakukanya dalam empat tahapan, yakni persiapan, pengkajian, perencanaan alternatif program atau kegiatan, pemformulasian rencana aksi, pelaksanaan program atau kegiatan, evaluasi, dan terminasi. Selanjutnya pengembangan potensi yang dilakukan Yayasan Kuntum ialah dengan melakukan serangkaian acara kegiatan, diantaranya training entrepreneur, charity creatifity, outbond on the road, dan juga melalui promosi UKM-UKM dengan berbagai media seperti internet, program televisi, dan seminar. Selanjutnya Peran Yayasan Kreativitas Unit Usaha Muslimah (KUNTUM) Indonesia dalam Mengurangi Pengangguran Melalui Praktik Kewirausahaan Sosial di Desa Tegal Waru Ciampea-Bogor oleh Bryan Wicaksono. ${ }^{16}$ Kajian tersebut berfokus pada bagaimana peran-peran yang dilakukan Yayasan Kuntum dalam kewirausahaan sosial untuk memecahkan masalah pengangguran di desa Tegalwaru. Hasil dari kajian tersebut menunjukkan bahwa ada peran Yayasan Kuntum dalam mengurangi pengangguran yang ada di desa Tegalwaru yaitu dibuktikan dengan terserapnya beberapa tenaga kerja ke dalam beberapa UKM yang ada, peran tersebut dicapai dengan memberikan pembiayaan makro, peningkatan kapasitas SDM, pelatihan wirausaha dan menjadikan desa Tegalwaru sebagai Kampung Wisata Bisnis serta mempromosikannya agar dikenal oleh masyarakat luas dengan bekerjasama bersama beberapa stasiun televisi dan media pemberitaan.

Bila diamati, studi-studi sebelumnya tidak mendekatinya dengan teori peran Jim Iffe dan Frank Tesoriero. Studi Peran Yayasan Kuantum di Kampung Wisata Bisnis Tegalwaru Ciampea Bogor ini, fokus kajian pada analisis peran-peran agen perubahan yang dilakukan oleh Yayasan

\footnotetext{
15 Ade Yunus Sukmana, "Strategi Pemberdayaan Ekonomi oleh Yayasan Kreativitas Usaha Unit Muslimah (KUNTUM) Indonesia Melahi Pengembangan Usaba Kecil Menengah (UKM) di Desa Tegal Waru Ciampea Bogor" (Skripsi Program Studi Kesejahteraan Sosial, Universitas Islam Negeri Syarif Hidayatullah Jakarta, 2015), 78-79.

16 Bryan Wicaksono, "Peran Yayasan Kreativitas Unit Usaha Muslimah (KUNTUM) Indonesia dalam Mengurangi Pengangguran Melalui Praktik Kewirausahaan Sosial di Desa Tegal Waru Ciampea-Bogor", (Skripsi Program Studi Kesejahteraan Sosial Universitas Negeri Islam Syarif Hidayatullah Jakarta, 2015).
} 
Kuantum dan Ibu Tatiek Kancaniati pada Komunitas Muslimah Kampung Wisata Bisnis Tegalwaru, dimana sejauh yang peneliti ketahui, studi mengenai analisis peran agen perubahan dalam pemberdayaan masyarakat masihlah sedikit. Studi ini membedah secara mendalam mengenai bentuk atau wujud dari peran agen perubahan dalam pemberdayaan di Komunitas Muslimah Kampung Wisata Bisnis Tegalwaru pada tahun 2009-2015. Dari situ menunjukkan bahwa studi ini berbeda dari studi-studi sebelumnya. Sehingga adanya studi ini diharapkan bukan hanya mengembangkan khazanah pengetahuan khususnya dalam bidang pemberdayaan masyarakat Islam saja, namun studi ini diharapkankan mampu mengawali pembahasan mengenai peran yang bisa dan harus dilakukan oleh agen perubahan sebagai penggerak, pendorong dalam aktifitas pemberdayaan masyarakat, dengan demikian ke depan, studi ini bisa diperdalam dan dikembangkan lagi.

\section{Metode}

Metodologi studi ini adalah kualitatif, penelitian ini merupakan penelitian kepustakaan (library research). Penelitian kepustakaan adalah penelitian yang dilakukan di perpustakaan atau museum terhadap bahanbahan berupa buku-buku, majalah, jurnal, hasil penelitian sebelumnya atau dokumen lainnya yang lainnya yang ada. ${ }^{17}$ Sumber data primer yang digunakan dalam studi ini adalah web official Kampoeng Wisata Bisnis Tegal Waru, instagram official Kampoeng Wisata Bisnis Tegal Waru, dan juga instagram resmi atau official dari Ketua Yayasan Kreativitas Unit Muslimah sementara untuk sumber data sekunder didapatkan secara tidak langsung dari subjek yang diteliti, yakni dari berbagai literatur terkait seperti penelitian terdahulu, jurnal, artikel terkait fenomena yang akan diteliti. ${ }^{18}$ Teknik pengumpulan data yang digunakan adalah pengumpulan data literer yaitu dengan mengumpulkan bahan-bahan pustaka yang berkesinambungan (koheren) dengan objek pembahasan yang diteliti. Sedangkan teknik analisa kualitatif pada studi ini, menggunakan model Miles dan Huberman yaitu reduksi data, penyajian data, dan penarikan kesimpulan. ${ }^{19}$

\footnotetext{
${ }^{17}$ Raichul Amar, Pengantar Metodologi Penelitian (Padang: Hayfa Press, 2007), 11.

18 Mestika Zeid, Metode Penelitian Kepustakaan (Jakarta : Yayasan Pustaka Obor Indonesia, 2004), 137.

${ }_{19}$ Mathhew B. Milles dan A. Michael Huberman, Analisa Data Kualitatif (Jakarta: UI Press, 1992), 15-16.
} 


\section{Hasil dan Pembahasan}

Dalam penyajian hasil dan pembahasan pada studi ini, akan ditampilkan berdasarkan pokok bahasan dalam hasil penelitian dalam dtudi ini, karena itu akan dibahas: (1) Peran agen perubahan; (2) Yayasan Kuntum Indonesia dan Kampung Wisata Tegalwaru Ciampea; (3) Peran Agen Perubahan Pada Kampung Wisata Ciampea Oleh Yayasan Kuntum Bogor; (4) Analisis Peran-Peran Agen Perubahan Pada Komunitas Muslimah di Kampung Wisata Ciampea Oleh Yayasan Kuntum Bogor.

\section{Peran Agen Perubahan}

Jenis-jenis peran yang dilakukan oleh agen perubahan dalam program pemberdayaan masyarakat, diantaranya: (1) Peran fasilitatif; (2) Peran edukasional; (3) Peran representatif; (4) Peran teknis. Teori ini banyak digunakan dalam menganalisis fenemena model peran yang diambil oleh pekerja sosial dalam mengawal proses pemberdayaan masyarakat, sebagaimana yang menjadi fokus studi ini juga. Adapun keempat peran di atas, di dalamnya masih terdapat sub-peran sebagaimana berikut $^{20}$ : pertama, di dalam peran fasilitatif, terdapat delapan sub-peran yang diantaranya: (a) Animasi sosial ${ }^{21}$, agen perubahan mendorong komunitas agar mau terlibat dalam proses pembangunan yang akan dilakukan; (b) Mediasi dan negosiasi ${ }^{22}$, agen perubahan berusaha menyelesaikan konflik yang terjadi didalam komunitas tanpa memihak kepada salah satu kelompok, (c) Pemberi dukungan ${ }^{23}$, agen perubahan mengembangkan dukungan agar komunitas semakin terdorong untuk

20 Isbandi Rukminto Adi, Intervensi Komunitas dan Pengembangan Masyarakat Sebagai Upaya Pemberdayaan Masyarakat (Jakarta: Rajagrafindo Persada, 2008), 217-225. Bandingkan dengan tulisan Jim Ife dan Frank Tesoriero, Community Development diterjemahkan oleh Sastrawan Manurung, Nurul Yakin, M.Nursyahid, disunting oleh Saifudin Zuhri Qudsi (Yogyakarta: Pustaka Pelajar, 2008), 547-629.

21 Isbandi Rukminto Adi, Intervensi Komunitas dan Pengembangan Masyarakat Sebagai Upaya Pemberdayaan Masyarakat (Jakarta: Rajagrafindo Persada, 2008), 217. Lihat juga tulisan Jim Ife dan Frank Tesoriero, Community Development diterjemahkan oleh Sastrawan Manurung, Nurul Yakin, M.Nursyahid, disunting oleh Saifudin Zuhri Qudsi (Yogyakarta: Pustaka Pelajar, 2008), 559.

22 Jim Ife dan Frank Tesoriero, Community Development diterjemahkan oleh Sastrawan Manurung, Nurul Yakin, M.Nursyahid, disunting oleh Saifudin Zuhri Qudsi (Yogyakarta: Pustaka Pelajar, 2008), 563-564. Bandingkan dengan tulisan Isbandi Rukminto Adi, Intervensi Komunitas dan Pengembangan Masyarakat Sebagai Upaya Pemberdayaan Masyarakat (Jakarta: Rajagrafindo Persada, 2008), 217-218.

23 Isbandi Rukminto Adi, Intervensi Komunitas dan Pengembangan Masyarakat Sebagai Upaya Pemberdayaan Masyarakat (Jakarta: Rajagrafindo Persada, 2008), 218. Lihat juga tulisan Jim Ife dan Frank Tesoriero, Community Development diterjemahkan oleh Sastrawan Manurung, Nurul Yakin, M.Nursyahid, disunting oleh Saifudin Zuhri Qudsi (Yogyakarta: Pustaka Pelajar, 2008), 566-567. 
terlibat aktif (d) Membentuk konsensus ${ }^{24}$, agen memiliki peran untuk merumuskan konsensus (mufakat bersama) yang mana bisa berfokus pada tujuan bersama, (e) Fasilitasi kelompok ${ }^{25}$, agen perubahan dituntut agar mampu memfasilitasi para kelompok tersebut untuk bisa sinergi dan saling mendukung atau melengkapi dalam proses pencapaian tujuan pembangunan; (f) Pemanfaatan sumber daya dan keterampilan ${ }^{26}$, agen perubahan harus mampu mengidentifikasi dan memanfaatkan sumber daya dan keterampilan yang dimiliki berbagai kelompok dalam komunitas; (g) Mengorganisasi ${ }^{27}$, agen perubahan juga memiliki peran untuk aktivitas merencanakan, menghitung kerealistisan tujuan, juga termasuk dalam pengadaan pertemuan dengan masyarakat; (h) Komunikasi personal ${ }^{28}$, agen perubahan dituntut agar mampu berkomunikasi secara personal kepada berbagai pihak yang berkaitan dengan komunitas yang diberdayakan.

Kedua, di dalam peran edukasional, terdapat empat sub-peran yang diantaranya: (a) Membangkitkan kesadaran masyarakat ${ }^{29}$, agen perubahan berusaha untuk membawa antar individu dalam komunitas untuk melihat permasalahannya secara makro dari perspektif sosial politik yang lebih luas; (b) Menyampaikan informasi ${ }^{30}$, agen perubahan perlu menyampaikan informasi atau pengetahuan yang belum diketahui oleh komunitasnya; (c) Mengkonfrontasikan ${ }^{31}$, ada kalanya, agen perubahan perlu melakukan konfrontasi kepada pihak-pihak yang mengganggu; (d) Pelatihan $^{32}$, agen perubahan memberikan pelatihan yang dibutuhkan oleh komunitas yang diberdayakan ataupun bisa mencarikan tenaga ahli yang bisa memberikan pelatihan yang dibutuhkan komunitas.

Ketiga, di dalam peran representatif, terdapat enam sub-peran yang diantaranya: (a) Memperoleh berbagai sumber daya ${ }^{33}$, peran ini berkaitan

\footnotetext{
${ }^{24}$ Isbandi Rukminto Adi, Intervensi Komunitas dan Pengembangan Masyarakat Sebagai Upaya

Pemberdayaan Masyarakat (Jakarta: Rajagrafindo Persada, 2008), 219.

25 Ibid, 220.

${ }^{26} \mathrm{Ibid}$.

27 Ibid.

${ }^{28}$ Ibid, 221

${ }^{29}$ Ibid 221-222. Lihat dan bandingkan dengan tulisan Jim Ife dan Frank Tesoriero, Community Development diterjemahkan oleh Sastrawan Manurung, Nurul Yakin, M.Nursyahid, disunting oleh Saifudin Zuhri Qudsi (Yogyakarta: Pustaka Pelajar, 2008), 583-585.

30 Isbandi Rukminto Adi, Intervensi Komunitas dan Pengembangan Masyarakat Sebagai Upaya Pemberdayaan Masyarakat (Jakarta: Rajagrafindo Persada, 2008), 222-223.

${ }^{31}$ Ibid, 223-224.

32 Ibid, 225.

33 Jim Ife dan Frank Tesoriero, Community Development diterjemahkan oleh Sastrawan Manurung, Nurul Yakin, M.Nursyahid, disunting oleh Saifudin Zuhri Qudsi (Yogyakarta: Pustaka Pelajar, 2008), 592-595.
} 
dengan bagaimana agen perubahan dituntut untuk mampu mencari dan mendapatkan akses informasi untuk memenuhi sumber daya yang dibutuhkan; (b) Advokasi ${ }^{34}$, peran ini bermakna bahwa agen perubahan menerima dan mewakili kepentingan komunitasnya untuk diangkat dalam proses pencapaian kesepakatan pada kasus-kasus tertentu; (c) Menggunakan media ${ }^{35}$, peranan ini berkaitan dengan perilaku agen perubahan yang berusaha menggunakan media sebagai alat untuk menempatkan program pemberdayaan yang dilakukannya agar bisa terpublikasi dan diketahui oleh masyarakat secara luas; (d) Hubungan masyarakat dan presentasi publik ${ }^{36}$, peran ini terkait dengan aktivitas yang dilakukan agen perubahan untuk mempublikasikan kepada masyarakat luas agar mendapatkan kesan bahwa program pemberdayaan yang dilakukannya di daerah tersebut membawa dampak positif; (e) Mengembangkan jaringan ${ }^{37}$, dalam peranan ini, agen perubahan menjalin hubungan kerja dengan berbagai pihak yang bisa mendukungnya untuk melakukan proses pembangunan; (f) Membagi pengetahuan dan pengalaman $^{38}$.

Keempat, di dalam peran teknis, terdapat lima sub-peran yang diantaranya: (a) Penelitian ${ }^{39}$, agen perubahan terlibat dalam proses penelitian untuk mengumpulkan data-data yang relevan, menganalisis dan kemudian mempresentasikannya; (b) Menggunakan komputer ${ }^{40}$, agen perubahan diharapkan mampu mengoperasikan komputer dan mendorong anggota komunitas untuk bisa mengoperasikannya juga; (c) Melakukan presentasi lisan dan tertulis ${ }^{41}$; (d) Manajemen ${ }^{42}$, agen perubahan berusaha melakukan manajemen atas pelaksanaan program pemberdayaan; (e) Pengelolaan keuangan ${ }^{43}$, peran ini meliputi peran berupa penyimpanan finansial yang memadai, akuntabilitas terhadap kontrol pengeluaran dan pemasukan program pemberdayaan yang sedang dilaksanakan.

\footnotetext{
34 Ibid, 595-597.

35 Ibid, 597-598.

36 Ibid, 598-600.

37 Ibid, 600-602.

38 Ibid, 602-603.

${ }^{39}$ Ibid, 604-608.

40 Ibid 608-609.

41 Ibid 609-610.

42 Ibid 611-613.

43 Ibid 613-614.
} 


\section{Yayasan Kuntum Indonesia dan Kampung Wisata Tegalwaru Ciampea}

Yayasan Kuntum Indonesia merupakan Yayasan yang berada di pedesaan, awal berdirinya Yayasan ini pada tanggal 18 Juni 2008, sejak itu dituntut untuk bisa berkiprah lebih banyak dalam melayani masyarakat, terutama dalam membantu meningkatkan kapasitas pemberdayaan ekonomi masyarakat melalui programnya yaitu "Kampung Wisata Bisnis Tegalwaru"(KWBT). Potensi masyarakat yang ada di sekitar Tegalwaru sebagian besar adalah pengrajin UMKM yang memiliki omset dan produksi yang sangat variatif dan baik. Berdirinya Yayasan Kuntum Indonesia ini dipelopori oleh dua orang, salah satunya adalah seorang wanita penduduk asli yang tinggal di Desa Tegal Waru yang bernama Ibu Tatiek Kancaniati. Beliaulah yang sampai saat ini berkonsentrasi penuh dalam memajukan wisata kampung ini. ${ }^{44}$

Dilatarbelakangi oleh potret kemiskinan masyarakat, yaitu pengetahuan mereka yang rendah, pembinaan yang kurang merata, produktifitas rendah, akses informasi dan kualitas Sumber Daya Manusia (SDM) yang rendah dan daya saing rendah. Berawal dari hal tersebut didirikannya Yayasan Kuntum Indonesia untuk memberikan ruang kepada anak-anak dan remaja bahkan para orang dewasa untuk mengekspresikan diri terutama untuk perkembangan jiwa entrepreneur. Agar turut serta berperan aktif dalam rangkaian kegiatan yang mengusung kepedulian terhadap pendidikan dan perekonomian anak bangsa dengan mengadakan Program Tour Kampung Wisata Bisnis sebagai program untuk mengasah jiwa bisnis dan pemahamanya tentang sebuah produk berbasis home industry. Untuk itu berkarya, berbudaya, dan berilmu bukan hanya menjadi sebuah slogan tapi harus diakui bahwa hal tersebutlah yang akan mengantarkan masyarakat pada tatanan kehidupan yang lebih baik dan memiliki keterampilan yang menghasilkan dari sisi finansial tentunya. ${ }^{45}$

Kampung Wisata Bisnis Tegalwaru (KWBT) memiliki visi, yakni: Menjadi Lembaga sosial entreprenur terdepan di Indonesia dalam mewujudkan SDM yang memiliki jiwa kepempinan dan pengabdian kepada masyarakat yang bersifat kreatif, inovatif dan solutif. Sementara misinya antara lain: 1) Menjadikan KWBT sebagai tempat studi wisata

\footnotetext{
${ }^{44}$ Bryan Wicaksono, "Peran Yayasan Kreativitas Unit Usaha Muslimah (KUNTUM) Indonesia dalam Mengurangi Pengangguran Melalui Praktik. Kewirausabaan Sosial di Desa Tegal Waru Ciampea-Bogor" (Skripsi Program Studi Kesejahteraan Sosial Universitas Negeri Islam Syarif Hidayatullah Jakarta, 2015), 47.

45 Ibid, 48-49.
}

50 Bela Kurnia \& Agus Susanto - Peran Yayasan KUNTUM 
bisnis berbasis home industri, 2) Mencetak SDM berjiwa sosial entreprenuer leader yang siap melakukan pengabdian di masyarakat, 3) Melatih SDM beriwa kepemimpinan yang cekatan dan terlatih dalam aspek bela diri dan kedisiplinan, 4) Menjadikan pusat inspirasi dan sinergitas social entrepreneur dunia berbasis pemberdayaan masyarakat, 5) Mewujudkan kemandirian masyarakat melalui pengembangan ekonomi kreatif, kewirausahaan dan parawisata, 6) Meningkatkan partisipasi dan interaksi sosial masyarakat dalam program pengembangan kawasan. ${ }^{46}$

\section{Peran Agen Perubahan Pada Kampung Wisata Ciampea Oleh Yayasan Kuntum Bogor}

Dalam membidani lahirnya kampung wisata bisnis di Komunitas Muslimah Tegalwaru Ciampea, Yayasan Kuntum Indonesia sebagai agen perubahan melakukan beberapa peran, diantaranya: pertama, peran fasilitatif, dalam memfasilitasi pemberdayaan di Tegalwaru Ciampea, Yayasan Kuntum Indonesia mendorong para pelaku usaha Komunitas Muslimah Tegalwaru agar mau menerima dan terlibat secara antusias dalam program Kampung Wisata Bisnis pada tahun 2009-2015. Yayasan Kuntum berusaha menjalin kerjasama dengan para pemilik UKM Tegalwaru agar mau bergabung menjadi mitranya dalam program KWBT, dan bersedia untuk menjadikan usahanya sebagai obyek percontohan bagi para wisatawan yang datang untuk belajar bisnis. ${ }^{47}$ Untuk meyakinkan para pemilik UKM agar mau bergabung menjadi mitra KWBT, Yayasan Kuntum juga menempuh jalan diskusi dengan para pelaku usaha Tegalwaru terkait pembagian hasil, dan kesediaan mereka memperkenalkan usahanya kepada wisatawan yang datang. Dalam hal peran mediasi dan negoisasi, Yayasan Kuntum Indonesia membuatkan aturan yang bisa menengahi apabila muncul ketidaksetujuan dalam hal ide dan semacamnya. Peraturan AD/ART yang dibuat oleh Yayasan Kuntum menjadi peraturan bersama yang harus ditaati baik oleh pengurus yayasan maupun para pelaku usaha yang menjadi mitranya dalam program KWBT. ${ }^{48}$ Yayasan Kuntum juga memberikan dukungan kepada para UKM Tegalwaru yang menjadi mitranya dengan cara membantu mereka dalam mempromosikan usahanya melalui berbagai

\footnotetext{
${ }^{46}$ Ibid.

47 Ade Yunus Sukmana, "Strategi Pemberdayaan Ekonomi oleh Yayasan Kreativitas Usaha Unit Muslimah (KUNTUM) Indonesia Melalui Pengembangan Usaba Kecil Menengah (UKM) di Desa Tegal Waru Ciampea Bogor", (Skripsi Program Studi Kesejahteraan Sosial, Universitas Islam Negeri Syarif Hidayatullah Jakarta, 2015) 78-80.

48 Ahmad Wiza Walady, "Evaluasi Program Yayasan Kuntum Indonesia Dalam Upaya Pengembangan UMKM di Kampung Wisata Bisnis Tegalwaru”, (Skripsi Program Studi Muamalat Ekonomi Islam Universitas Islam Negeri Syarif Hidayatullah Jakarta, 2015) 89-91.
} 
saluran informasi, seperti internet, majalah, televisi, program talkshow, dan lain-lain. ${ }^{49}$ Yayasan Kuntum menawarkan bantuan dana untuk para UKM yang membutuhkan hal tersebut untuk keperluan pengembangan usahanya, namun ada mekanisme seleksi, dilakukan dengan menilai apakah UKM tersebut terlibat dengan bank keliling atau tidak, jika ada yang terlibat maka yayasan terpaksa tidak bisa memberikan bantuan biaya kepada UKM tersebut. ${ }^{50}$ Dalam hal peran membentuk konsensus, Yayasan Kuntum Indonesia diketahui melakukan pemufakatan dengan warga Tegalwaru terkait program KWBT selama tahun 2009-2015, sehingga mereka bisa menerima atau mengizinkan adanya program tersebut, tetap bersikap solid dalam satu visi yang sama yaitu membangun desa bersama, walaupun tidak harus bergabung sebagai mitra program KWBT. ${ }^{51}$ Yayasan Kuntum juga mengidentifikasi serta memanfaatkan sumber daya dan keterampilan yang dimiliki oleh warga Tegalwaru, khususnya dari para UKM yang menjadi mitranya, bentuk kongkrit akan hal tersebut diantaranya melakukan observasi kepada para UKM yang ada di desa Tegalwaru dengan cara mendatangi mereka langsung, untuk menilai potensi yang dimiliki tiap UKM, setelah itu ada proses penyeleksian bagi UKM-UKM yang potensial untuk dikembangkan dan akan diajak kerjasama dengan Yayasan Kuntum. ${ }^{52}$ Dari hasil observasi dan seleksi tersebut dipertemukan dengan adanya kebutuhan akan inspirasi bisnis dari masyarakat umum, kemudian dibentuklah ide untuk menjadikan desa Tegalwaru sebagai Kampung Wisata Bisnis, yang didalamnya nanti akan menjual tiga produk wisata yang ditawarkan kepada wisatawan yang datang berkunjung, yakni: (1) Training entrepreneur, (2) Charity creativity, (3) Outbound on the road. Yayasan Kuntum juga memanfaatkan adanya Rumah Joglo untuk dijadikan tempat pelaksanaan pelatihan, penginapan serta kegiatan pelayanan kepada para pelanggan. ${ }^{53}$ Jika ada pengunjung yang datang, Yayasan tidak

49 Ade Yunus Sukmana, "Strategi Pemberdayaan Ekonomi oleh Yayasan Kreativitas Usaha Unit Muslimah (KUNTUM) Indonesia Melahi Pengembangan Usaba Kecil Menengab (UKM) di Desa Tegal Waru Ciampea Bogor", (Skripsi Program Studi Kesejahteraan Sosial, Universitas Islam Negeri Syarif Hidayatullah Jakarta, 2015) 72.

${ }^{50}$ Yulia Yusnita, "Entrepreneur Yayasan KUNTUM Indonesia dalam Pemberdayaan Ekonomi Keluarga di Desa Tegal Waru Kecamatan Ciampea Kabupaten Bogor", (Skripsi Program Studi Pengembangan Masyarakat Islam Universitas Islam Negeri Syarif Hidayatullah Jakarta, 2014) 96.

51 Membangun dari Desa, Jangan ke Kota Melulu, video YouTube, 24.26 - 25.05, di unggah oleh "Helmy Yahya Bicara" 19 Juli, 2020, dalam https://youtu.be/DQsiZPYhsqU.

52 Ade Yunus Sukmana, "Strategi Pemberdayaan Ekonomi oleh Yayasan Kreativitas Usaha Unit Muslimah (KUNTUM) Indonesia Melalui Pengembangan Usaba Kecil Menengab (UKM) di Desa Tegal Waru Ciampea Bogor" (Skripsi Program Studi Kesejahteraan Sosial, Universitas Islam Negeri Syarif Hidayatullah Jakarta, 2015) 60.

${ }^{53}$ Retno Kusumastuti, Eko Sakapurnama, Achmad Fauzi, Prima Nurita "Understanding Business Model of Social Innovation : Kajian Desa Wisata Bisnis Tegalwaru" Jurnal Pemikiran dan Penelitian Administrasi Bisnis dan Kewirausahaan” Vol. 3, no. 4 (2018), 138. 
bisa menyertakan semua UMKM mitranya untuk dikunjungi home industry nya, hal ini dikarenakan penunjukan tempat kunjungan itu sendiri yayasan berikan kuasa kepada pengunjung untuk memilih tempat yang mau dikunjungi. ${ }^{54}$

Kedua, peran edukasional yang dilakukan oleh Yayasan Kuntum Indoinesia sebagai agen perubahan, di awal pembentukan Kampung Wisata Ciampea adalah berusaha menyadarkan masyarakat bahwa mereka memiliki masalah yang harus dipecahkan, serta meyakinkan mereka bahwa program KWBT yang diinisiasinya adalah solusi yang tepat atas permasalahan mereka selama ini, sehingga mereka bisa mengadakan perubahan yang signifikan dalam kehidupannya dengan bergabung bersama program tersebut. ${ }^{55}$ Setelah Yayasan Kuntum hadir, mereka dibekali dengan diberikan wawasan tentang kewirausahaan dan dilatih berwirausaha agar mereka bisa lebih maju lagi.

Ketiga, peran representatif yang dilakukan oleh Yayasan Kuntum Indonesia sebagai agen perubahan, yakni mencari akses informasi yang dibutuhkan dengan melakukan interaksi kepada pihak-pihak eksternal yang bisa memenuhi sumber daya yang diperlukan untuk mewujudkan dan melaksanakan program KWBT. Yayasan Kuntum menempuh beberapa upaya untuk mewujudkan program KWBT nya, komunikasi terhadap birokrasi setempat pun dilakukan. ${ }^{56}$ Sedangkan dalam rangka memenuhi kebutuhan permodalan untuk program KWBT, ibu Tatiek mendapatkannya dari beberapa sumber pendanaan yaitu investor, LSM, dan dari uang pribadi. ${ }^{57}$ Yayasan Kuntum memang menempuh beberapa cara untuk membantu mempromosikan usaha mereka, beberapa diantaranya adalah melalui berbagai saluran informasi, seperti internet, majalah, "Menggagas dan bekerjasama dengan seluruh elemen masyarakat mengembangkan KWBT dan diliput dan ditayangkan oleh TRANS TV, ANTV, MNC TV, METRO TV, DETIK.COM,

\footnotetext{
54 Ahmad Wiza Walady, "Evaluasi Program Yayasan Kuntum Indonesia Dalam Upaya Pengembangan UMKM di Kampung Wisata Bisnis Tegalwaru” (Skripsi Program Studi Muamalat Ekonomi Islam Universitas Islam Negeri Syarif Hidayatullah Jakarta, 2015), 96.

55 Ade Yunus Sukmana, "Strategi Pemberdayaan Ekonomi oleh Yayasan Kreativitas Usaha Unit Muslimah (KUNTUM) Indonesia Melahi Pengembangan Usaba Kecil Menengah (UKM) di Desa Tegal Waru Ciampea Bogor" (Skripsi Program Studi Kesejahteraan Sosial, Universitas Islam Negeri Syarif Hidayatullah Jakarta, 2015), 112.

56 Membangun dari Desa, Jangan ke Kota Melulu, video YouTube. 16.48-17.50 , di unggah oleh "Helmy Yahya Bicara" 19 Juli, 2020, dalam https://youtu.be/DQsiZPYhsqU.

57 Yulia Yusnita, "Entrepreneur Yayasan KUNTUM Indonesia dalam Pemberdayaan Ekonomi Keluarga di Desa Tegal Waru Kecamatan Ciampea Kabupaten Bogor" (Skripsi Program Studi Pengembangan Masyarakat Islam Universitas Islam Negeri Syarif Hidayatullah Jakarta, 2014), 57.
} 
MEGASWARA, program talk show dan lain-lain." ${ }^{58}$ KWBT telah mampu membuat website sendiri dengan nama wisatabisnistegalwaru.com. Di dalam website, terdapat laman yang berisi pengenalan singkat tentang KWBT, serta beberapa artikel yang berisi tentang dokumentasi beberapa kunjungan dari wisatawan yang datang ke KWBT, dan memposting ulang artikel dari beberapa website lainnya. ${ }^{59}$ Di platform media sosial instagram, Yayasan Kuntum melalui akun official ibu @tatiek_kancaniati dan akun@tegalwarukreatif aktif membagikan postingan tentang dokumentasi wisatawan yang telah datang berkunjung ke KWBT, serta promosi produk hasil UKM. Dalam mengembangkan jaringan, Ibu Tatiek selaku ketua Yayasan Kuntum Indonesia menempuh beberapa upaya untuk mewujudkan program KWBT nya, komunikasi terhadap birokrasi setempat pun dilakukan. Dalam menjalin kerjasama dengan pihak eksternal, Yayasan Kuntum tidak pernah mau menerima dana tertentu dengan mengandung perintah dari si pemberi agar Yayasan Kuntum melakukan sesuatu secara pribadi. Walaupun ada beberapa partai yang mengajak bu Tatiek untuk masuk ke bidang politik mereka agar lebih mudah mendapatkan suara, bu Tatiek menolaknya. ${ }^{60}$ Namun, jika pemberian bantuan tersebut disertai dengan atribut partai, asalkan tetap berniat membantu warga, maka bu Tatiek memperbolehkannya. ${ }^{61}$

Keempat, beberapa peran Teknis juga dilakukan oleh agen perubahan, dalam penelusuran data, ditemukan bahwa agen perubahan memiliki peran penelitian, misalnya upaya awal yang dilakukan agen perubahan sebelum menawarkan konsep Kampung Wisata Bisnis, menemukan adanya beragam masalah sosial di desa Tegalwaru, seperti tingginya angka kemiskinan, jumlah pengangguran, angka putus sekolah, pernikahan dini, dan lain sebagainya, membuat Ibu Tatiek berupaya mencari cara untuk menemukan solusinya. ${ }^{62}$ Setelah agen perubahan mengidentifikasi adanya masalah yang ada pada para pelaku usaha di Tegal Waru, ia menemukan bahwa pemasaran produk yang mereka lakukan masih belum efektif. ${ }^{63}$ Salah satu penggunaan komputer

\footnotetext{
${ }^{58}$ Ibid, 90.

${ }^{59}$ Dalam https://www.wisatabisnistegalwaru.com/2017/07/ diakses pada tanggal 20 September, 2020.

60 Ahmad Wiza Walady, "Evaluasi Program Yayasan Kuntum Indonesia Dalam Upaya Pengembangan UMKM di Kampung Wisata Bisnis Tegalwaru" (Skripsi Program Studi Muamalat Ekonomi Islam Universitas Islam Negeri Syarif Hidayatullah Jakarta, 2015), 93.

${ }^{61}$ Ibid.

62 Ade Yunus Sukmana, "Strategi Pemberdayaan Ekonomi oleh Yayasan Kreativitas Usaha Unit Muslimah (KUNTUM) Indonesia Melalui Pengembangan Usaha Kecil Menengah (UKM) di Desa Tegal Waru Ciampea Bogor" (Skripsi Program Studi Kesejahteraan Sosial, Universitas Islam Negeri Syarif Hidayatullah Jakarta, 2015), 78-79.

${ }^{63}$ Ibid, 83.
} 
dilakukan ibu Tatiek untuk pemasaran produk hasil mitra UKMnya serta untuk keperluan publikasi kegiatan KWBT agar mengundang banyak wisatawan datang kesana. ${ }^{64}$ Yayasan Kuntum juga menggunakannya pada saat mengisi materi pelatihan bisnis kepada wisatawan yang datang ke desanya, seperti yang ditunjukkan pada video YouTube "Desa Wisata Bisnis Tegalwaru" yang di unggah oleh channel Fira Asikin. ${ }^{65}$ Sedangkan pada tahun awal pendirian KWBT, ibu Tatiek yang aktif merancang pembuatan pamflet dan website resmi dikarenakan warga pada saat itu belum tahu bagaimana penggunaan komputer. Yayasan Kuntum selaku agen perubahan juga melakukan presentasi secara lisan kepada perangkat desa Tegalwaru, mulai dari kepala desa, kelurahan, hingga kecamatan. Yang dipresentasikan adalah tentang ide KWBT yang dimilikinya. ${ }^{66}$ Sedangkan untuk presentasi secara tertulis dilakukan Yayasan Kuntum melalui website resmi wisatabisnistegalwaru.com yaitu dengan membuat artikel tentang profil KWBT, profil ibu Tatiek selaku pendiri, dan paket wisata yang ditawarkan didalamnya. ${ }^{67}$ Terkait dengan upaya Yayasan Kuntum dalam melakukan manajemen atas pelaksanaan program KWBT pada tahun 2009-2015. Setelah mengantongi ide pendirian KWBT, Yayasan Kuntum membentuk kader lokal seperti PKK, Karang Taruna dan Kelompok Usaha Mandiri yang diharapkan mampu mengoptimalkan kesadaran dan potensi sosial-ekonomi warga Tegalwaru, sehingga bisa mendorong hadirnya inovasi produk yang lahir dari kreatifitas warga, serta semakin dikenal oleh banyak orang, dan bisa berefek pada penambahan hasil penjualan. ${ }^{68}$ Dalam mengisi kebutuhan SDM, Yayasan Kuntum memberikan peluang terhadap siapa saja yang mau bergabung selama mereka memenuhi kriteria yang telah ditetapkan yaitu amanah dan kemauan untuk berjuang. ${ }^{69}$ Yayasan Kuntum masih belum memiliki catatan-catatan laporan keuangan perbulan diakibatkan jumlah

${ }^{64}$ Gustyanita Pratiwi, "Tatiek Kancaniati:Perintis Kampoeng Wisata Bisnis Tegalwaru” SWA, 3 Februari, 2014 dalam https://swa.co.id/swa/headline/tatiek-kancaniati-perintis-kampoengwisata-bisnis-tegalwaru (diakses pada tanggal 01 September, 2020).

${ }^{65}$ Desa Wisata Bisnis Tegalwaru, video YouTube, 3.03 - 3.08, di unggah oleh "Fira Asikin" pada tanggal 12 Agustus, 2014 dalam https://youtu.be/rQvTDwVRN5I.

66 Gustyanita Pratiwi, "Tatiek Kancaniati:Perintis Kampoeng Wisata Bisnis Tegalwaru" SWA, 3 Februari, 2014 dalam https://swa.co.id/swa/headline/tatiek-kancaniati-perintis-kampoengwisata-bisnis-tegalwaru (diakses pada tanggal 01 September, 2020).

${ }^{67}$ Dalam https://www.wisatabisnistegalwaru.com/ diakses pada tanggal 22 Oktober, 2020.

68 Yulia Yusnita, "Entrepreneur Yayasan KUNTUM Indonesia dalam Pemberdayaan Ekonomi Keluarga di Desa Tegal Waru Kecamatan Ciampea Kabupaten Bogor" (Skripsi Program Studi Pengembangan Masyarakat Islam Universitas Islam Negeri Syarif Hidayatullah Jakarta, 2014), 56.

69 Ahmad Wiza Walady, "Evaluasi Program Yayasan Kuntum Indonesia Dalam Upaya Pengembangan UMKM di Kampung Wisata Bisnis Tegalwaru" (Skripsi Program Studi Muamalat Ekonomi Islam Universitas Islam Negeri Syarif Hidayatullah Jakarta, 2015) 96-97. 
donaturnya sedikit sehingga tak dicatat, dan ada juga yang tidak mau dicatat donasinya.

\section{Analisis Peran-Peran Agen Perubahan Pada Komunitas Muslimah di Kampung Wisata Ciampea Oleh Yayasan Kuntum Bogor}

Berdasarkan pemaparan data di atas, dapat dianalisis sebagai berikut bahwa dalam melakukan pemberdayaan masyarakat di Komunitas Muslimah Kampung Wisata Ciampea, Yayasan Kuntum dalam melakukan peran-peran fasilitasi, animasi sosial yang dilakukan yakni dengan mengkomunikasikan idenya kepada masyarakat, melakukan pendekatan baik secara personal yakni mengunjungi rumah produksi pelaku usaha yang ada di Tegalwaru, juga secara berkelompok dengan melibatkan diri di dalam forum-forum pertemuan antara birokrasi desa dengan warga Tegalwaru. Upaya ini dipilih dan dilakukan dengan maksud untuk memberi ruang kepada masyarakat agar bisa menilai dan merespon secara langsung atas inovasi pembentukan program KWBT tersebut, sehingga komunitas terdorong untuk mauterlibat aktif dalam proses pemberdayaan Kampung Wisata Bisnis Tegalwaru. Dalam hal mediasi dan negoisasi, rupanya Yayasan Kuantum Indonesia memilih cara yakni membuatkan aturan main yang disepakati secara kolektif, dari pemaparan di atas, penyelesaian yang dilakukan oleh agen perubahan mengembalikan ketidak setujuan bila ada, pada AD/ART serta aturan terkait mengenai pendirian Kampung Wisata Bisnis itu sendiri, hal ini menurut penulis sangat efektif dan efisien dalam melakukan negoisasi dan mediasi dalam proses pemberdayaan masyarakat, bila ada ketidaksepakatan dalam prosesnya, mereka akan berupaya untuk refleksi terhadap motif pendirian Kampung Wisata. Yayasan Kuntum memberikan peran kepada para UKM tersebut untuk secara aktif berinteraksi dengan pengunjung yang datang ke home industry nya.

Dalam hal pemanfaatan sumber daya dan keterampilan, dari data di atas, Yayasan Kuntum bisa menemukan masalah sekaligus potensi yang ada dalam para pelaku usaha di Tegalwaru, secara potensial adalah usahausaha mereka sebenarnya kreatif, dan bermacam-macam jenisnya mulai dari pembuatan wayang, golok, pembibitan ikan, pembuatan kerupuk, obat herbal, dan lain-lain, namun ada kondisi yang sama yang dialami oleh para pelaku usaha tersebut, yakni ibu Tatiek melihat industri mereka kurang berkembang, serta pola pemasaran yang dilakukan itu sifatnya masih konvensional seperti berkeliling menjajakan produk, menunggu pesanan, dan dititipkan ke warung. Yayasan Kuntum juga telah mengorganisasi pengelolaan KWBT tidak secara sepihak dalam 
menetapkan hal-hal yang bersangkutan dengan peran yang dimiliki mitra UKM nya. Seperti halnya saat mendapatkan pesan dari wisatawan yang akan berkunjung ke KWBT ataupun saat ada kontrak kegiatan dengan lembaga tertentu, maka hal yang pertama dilakukannya adalah memastikan jadwalnya kapan, berapa orang yang akan datang, program wisata apa yang dipilih, termasuk UKM mana yang akan dikunjungi untuk dipelajari bisnisnya oleh mereka. Sedangkan peran komunikasi personal dilakukan Yayasan Kuntum kepada warga Tegalwaru sebagai obyek sasaran pemberdayaan yang dilakukannya, kepada birokrasi setempat (kelurahan dan kecamatan) untuk mendapatkan dukungan serta izin pendirian program, serta kepada salah satu LSM yang diajaknya berdiskusi terkait ide KWBT yang dimilikinya tersebut. Upaya lainnya dilakukan dengan mengunjungi rumah industri mereka satu persatu untuk menjelaskan tentang adanya ide pembentukan KWBT sekaligus mengajak mereka untuk bergabung agar mau bekerjasama dengan Yayasan Kuntum sebagai mitra bisnis dalam program tersebut.

Untuk peran edukasionalnya, berdasarkan paparan data diatas, Yayasan Kuntum berusaha menyadarkan para UKM Tegalwaru bahwa sebenarnya mereka bisa mengadakan perubahan atas kehidupannya, dan jangan hanya stagnan pada kondisinya sekarang. Hal tersebut bukanlah hal yang mudah, mengingat para UKM sudah terbiasa bertahun-tahun menjalankan usahanya dengan cara yang konvensional, ditambah mereka tidak memiliki update pengetahuan tentang bagaimana seharusnya melakukan promosi produk di masa yang sudah serba teknologi seperti sekarang, tentunya mereka bisa jadi belum sadar betul bagaimana pentingnya peran ilmu pengetahuan dan teknologi untuk kemajuan usahanya. Dari sana mereka sadar, bahwa peningkatan terhadap kehidupannya tersebut juga bisa memunculkan kebutuhan baru yang mana kebutuhan tersebut bisa diisi dengan cara turut mengajak orangorang disekitarnya untuk menjadi tenaga produktif, mereka bisa menyerap tenaga pengangguran yang ada di Tegalwaru, turut berperan dalam proses pengentasan kemiskinan yang selama ini belum terpecahkan. Yayasan Kuntum membekali para UKM Tegalwaru yang menjadi mitranya dengan wawasan dan pelatihan kewirausahaan, khususnya yang terkait dengan pemasaran produk. Pendekatan yang dilakukan tidak hanya tutorial menjelaskan teori, tapi mereka juga diajak secara langsung untuk mendapatkan pengalaman terkait hal tersebut, seperti diajak ke seminar dan diberi kesempatan untuk berbicara menjelaskan usahanya kepada peserta yang hadir, mengadakan bazaar untuk mempromosikan produknya, diajari pemasaran melalui media internet, dan dilatih untuk siap berinteraksi dengan pengunjung yang 
datang ke KWBT, dan menjelaskan tentang usaha mereka tekuni, serta bisa mengajari pengunjung jika mengadakan pelatihan kewirausahaan di UKM tersebut. Peran menyampaikan informasi dan pelatihan yang dilakukan terbukti cukup berhasil mendorong mitra UKM sukses.

Dalam memperoleh berbagai sumber daya agar terwujudnya KWBT, Yayasan Kuntum dalam permodalan, menggunakan dari modal pribadi yang dikelola seefisien mungkin untuk bisa mengoperasikan program, namun seiring berjalannya waktu, dikarenakan perkembangan KWBT semakin pesat, Yayasan Kuntum berusaha menjalin hubungan kerjasama dengan beberapa lembaga, termasuk dengan pemerintah kabupaten untuk mendapatkan bantuan permodalan. Terkait dengan peran humas dan presentasi publik, agen perubahan memakai cara mempertemukan antara para pelaku UKM binaan dengan pengunjung dengan sedemikian rupa, penataan yang dilakukan secara tidak lamgsung telah berfungsi sebagai penjelas dari Kampung Wisata tersebut, pengunjung bukan hanya membeli produk namun diberikan kesempatan untuk mengenal produk UKM dengan baik, sehingga mereka merasakan kepuasan sebagai konsumen. Beberapa mitra UKM Yayasan Kuntum sering menjelaskan tentang bagaimana perubahan yang mereka rasakan sejak bergabung dengan KWBT. Mengenai peran berbagi pengetahuan dan pengalaman, Yayasan Kuntum dalam prosesnya menekankan agar para pelaku UKM Tegalwaru nantinya bisa berbagi pengetahuan dan pengalaman dalam mengelola UKM sebagaimana yang telah diberikan atau diajarkan oleh Ibu Tatiek selaku ketua Yayasan Kuantum Indonesia. Misalnya ibu Tatiek juga mempersilahkan bagi para mitra UKM nya untuk berinteraksi dengan pengunjung, mereka kemudian menggunakan kesempatan itu untuk berbagi pengetahuannya dan pengalaman tentang usaha yang mereka rintis selama ini, baik dari bagaimana cara membuatnya, menjualnya kemana, termasuk menceritakan bagaimana sejarah pendirian usaha mereka yang bisa menginspirasi pengunjung.

Yayasan Kuntum juga memanfaatkan peran komputer sebagai alat untuk membuat media promosi seperti pembuatan pamflet, website resmi dan pembuatan toko online. Dalam penggunaan komputer tersebut, ibu Tatiek juga melibatkan para UKM Tegalwaru dengan mengajari mereka terlebih dahulu bagaimana cara mempromosikan produk melalui internet, setelah itu pengelolaan toko online diserahkan kepada masing-masing UKM. Yayasan Kuntum aktif melakukan presentasi baik secara lisan maupun tertulis kepada birokrasi setempat, pengunjung, dan masyarakat luas melalui perantara media. Presentasi lisan yang dilakukan ibu Tatiek biasanya dilakukan ketika dirinya menjadi pengisi pelatihan bisnis kepada 
pengunjung. Ibu Tatiek juga melakukan presentasi lisan melalui media liputan televisi maupun video YouTube, disana ibu Tatiek berusaha memberikan penjelasan yang mudah dipahami, dan menunjukkan bahwa KWBT layak dikunjungi untuk berwisata sekaligus mendapatkan inspirasi bisnis, yang mana ditempat lain tidak bisa didapatkan. Sedangkan, upaya presentasi secara tertulis dilakukan melalui website resmi KWBT dengan penjelasan yang sederhana tentang profil KWBT, dan penjelasan ibu Tatiek sebagai founder dijelaskan secara menarik untuk dijadikan sebagai inspirasi. Peran manajemen, dilakukan dengan membentuk kelompok seperti PKK, Karang Taruna untuk aktif mensosialisasikan kepada warga Tegalwaru agar mereka semakin sadar terhadap potensi yang dimilikinya, dan mau untuk mengembangkan hal tersebut. Kemudian, untuk menggerakkan UKM Tegalwaru agar mau menjadi mitranya, Yayasan Kuntum berdiskusi untuk menetapkan prosentase pembagian hasil kunjungan sebagai feedback atas peran mereka dalam KWBT, serta mereka juga tidak tiba-tiba menjalankan tugasnya tetapi akan dibantu terlebih dahulu oleh Yayasan Kuntum dengan cara dibekali pengetahuan serta pelatihan untuk siap berbagi ilmunya kepada pengunjung. Diharapkan dengan strategi penggerakan tersebut, mitra UKMnya bisa menjalankan apa yang menjadi tugasnya nanti saat pelaksanaan KWBT. Dalam pengelolaan pengeluaran keuangan, Yayasan Kuntum memfokuskan pada pemenuhan kebutuhan sarana dan prasarana, namun juga tetap memberi porsi untuk memberikan bantuan kepada UKM yang membutuhkan, namun dengan persyaratan yang cukup ketat demi menjamin bahwa peminjaman dana tersebut untuk hal yang produktif sehingga tingkat kepastian pengembaliannya lebih tinggi, selain itu juga untuk membuat sistem agar para UKM tidak sembarangan meminjam uang kepada Yayasan, kecuali untuk hal-hal yang memang diperlukan demi kebutuhan usahanya. Di samping pendasaran itu, Yayasan Kuntum juga menghitung kerealistisan kemampuan finansial yang ada untuk memberikan bantuan pinjaman modal kepada UKM Tegalwaru. Namun Yayasan Kuntum masih belum memiliki catatan-catatan laporan keuangan perbulan diakibatkan jumlah donaturnya sedikit sehingga tak dicatat, dan ada juga yang tidak mau dicatat donasinya.

\section{Kesimpulan dan Saran}

Dari studi yang telah dilakukan untuk menjawab rumusan masalah "Bagaimana Peran Yayasan Kuntum di Komunitas Muslimah Kampung Wisata Bisnis Tegalwaru pada tahun 2009-2015?" dapat disimpulkan bahwa: 
Yayasan Kuntum melakukan peran-peran fasilitatif seperti animasi sosial dengan aktif menjadi subjek yang mensosialisasikan ide tentang KWBT terhadap warga Tegalwaru khususnya kepada para pelaku usaha dan kepada birokrasi desa Tegalwaru, dalam hal mediasi dan negoisasi Yayasan Kuntum memilih untuk membuatkan aturan main yakni AD/ART yang disepakati secara kolektif, Yayasan Kuntum memberikan peran kepada para UKM tersebut untuk secara aktif berinteraksi dengan pengunjung yang datang ke bome industry nya. Dalam hal pemanfaatan sumber daya dan keterampilan, Yayasan Kuntum mampu menemukan dan memanfaatkan potesi sumber daya yang belum teroptimalkan yakni keanakeargaman bentuk usaha yang dirintis sebelumnya. Peran mengorganisasikan telah berhasil dilakukan yakni mengatur sedemikian rupa antara UKM-UKM binaan dengan pengunjung, pertemuan itu terbukti membutuhkan kalkulasi antara tujuan dengan keadaan aktual UKM binaan, sehingga mampu dipertemukan dengan pengunjung potensial.

Untuk peran edukasional, Yayasan Kuntum berusaha membangkitkan kesadaran para UKM Tegalwaru agar mau tergerak mengadakan perubahan atas kehidupannya dengan aktif memberikan wawasan dan pelatihan kewirausahaan kepada mereka, serta membuat mereka sadar tentang peran penting ilmu pengetahuan dan teknologi untuk kemajuan usaha mereka kedepannya melalui upaya pemberian pelatihan pemasaran menggunakan media online seperti menggunakan media sosial, website resmi KWBT, serta online shop.

Yayasan Kuntum juga melakukan peran representatif dengan berupaya untuk mencari sumber daya yang dibutuhkan dalam pelaksanaan KWBT, dengan cara berusaha melegalkan pendirian program, menjalin kerjasama dengan berbagai lembaga eksternal untuk mendapatkan dukungan, mengembangkan jaringan dengan warga diluar Tegalwaru, menggunakan peran media sosial, website, liputan televisi, dan video YouTube untuk keperluan publikasi kegiatan dalam KWBT serta mempromosikan produk hasil UKM Tegalwaru. Selain itu, juga aktif berbagi pengetahuan dan pengalaman kepada masyarakat luas untuk menularkan inspirasi pemberdayaan berbasis kewirausahaan sosial. Yayasan Kuntum terbukti mampu mendapatkan sumber pendanaan dari investor, LSM dan uang pribadi dengan ketentuan tidak merugikan UKM binaan.

Yang terakhir, untuk peran teknis, Yayasan Kuntum melakukan peran penelitian, telah berhasil mengidentifikasi substansi masalah warga 
Tegalwaru dengan melakukan observasi dan langkah penyelidikan yang ilmiah. Sehingga Yayasan Kuntum mamu merumuskan solusi yang tepat, mempersiapkan para UKM agar siap berbagi ilmu dan kemampuannya ketika bertemu dengan wisatawan KWBT. Selain itu, Yayasan Kuntum juga melakukan manajemen atas pelaksanaan program, dan pengelolaan keuangan didalamnya.

Saran yang bisa diberikan dalam studi ini berdasarkan temuantemuan serta proses dalam pembuatan studi ini, bahwa kesuksesan Yayasan Kuntum dalam mengelola pelaksanaan KWBT menjadi hal yang layak untuk dipelajari lebih dalam dengan sudut pandang disiplin ilmu yang lainnya agar bisa menjadi beragam pengetahuan baru yang bermanfaat diterapkan sebagai alternatif pemecahan masalah. Hasil penelitian diatas terbatas pada temuan tentang peran Yayasan Kuntum di KWBT selama tahun 2009-2015, sehingga untuk penelitian selanjutnya bisa mengeksplorasi peran Yayasan Kuntum pada tahun-tahun selanjutnya dengan menggunakan metode penelitian yang lebih komprehensif, serta bisa mengambil topik penelitian dengan tema yang selainnya, seperti mengeksplorasi model kewirausahaan sosial yang diterapkan Yayasan Kuntum melalui inovasi KWBT yang cukup unik dan baru satu-satunya di Indonesia namun ternyata bisa efektif memecahkan masalah pemasaran yang dihadapi para UKM des Tegalwaru.

\section{DAFTAR PUSTAKA}

Aprianto, Eko. "Tatiek Kancaniati, Sang Pelopor Kampung Wisata Bisnis Tegal Waru," Bina Swadaya, 22 Oktober, 2013, https://binaswadaya.org/id/2013/10/22 (diakses pada tanggal 5 Juni, 2020).

Ayu Prahasty, Sheylla, Diana Amaliasari, Qoute Nuraini C "Strategi Komunikasi Bisnis di Kampung Wisata Bisnis Tegal Waru Ciampea Kabupaten Bogor". Jurnal APIK Vol 1 No.2, 2019.

Departemen Agama Republik Indonesia. Mushaf Al-Qur'an Terjemah. Jakarta: Al-Huda, 2005.

Departemen Pendidikan dan Kebudayaan, Kamus Besar Bahasa Indonesia. Jakarta: Balai Pustaka, 1998.

Firmansyah "Desa Wisata Ngelanggeran Sebagai Destinasi Wisata Berbasis Ekowisata Di Yogyakarta" Makalah laporan Domestic Case Study, Sekolah Tinggi Pariwisata Ambarrukmo Yogyakarta, 2018. 
Hamdani Nugraha, Ilham, "Peran Change Agen Sebagai Faktor Penyebab Keberbasilan Pemberdayaan Pemuda Oleb Kelompok Penangkaran Bibit Kreatif Mandiri Desa Buabdua Kecamatan Buabdua Kabupaten Seumedang. Skripsi Program Studi Pendidikan Luar Sekolah Universitas Pendidikan Indonesia Bandung Jawa Barat, 2014.

Hidayati, Rini, Muslikh, Nazwirman "Pelatihan Dalam Upaya Meningkatkan Daya Saing Produk. UKM Kampung Wisata Bisnis Tegal Wari Bogor". Jurnal Ilmiah Pengabdian Masyarakat Vol. 2 no. 1, 2018.

Ife, Jim dan Frank Tesoriero, Community Development, diterjemahkan oleh Sastrawan Manurung, Nurul Yakin, M.Nursyahid, disunting oleh Saifudin Zuhri Qudsi, Yogyakarta : Pustaka Pelajar, 2008.

Indrawati, dan Sukma Paramastuti. "Intervensi Komunitas "Rifka Annisa" Yogyakarta Pada Perempuan Korban Kekerasan Dalam Rumah Tangga." INTELEKSIA-Jurnal Pengembangan Ilmu Dakwah 1.02, 2020.

Ismail, Nawari, Metodologi Penelitian Untuk Studi Islam. Yogyakarta : Samudra Biru, 2015.

Juwita, Rahma, Nelfa Roza, Ikhsan Mulkhairi “Artikel Konsep dan Peranan Agen Perubahan", 2019.

Khadijah, Siti. "Komunikasi Partisipatif Dalam Pembentukan Kampoeng Wisata Bisnis Tegalwaru (KWBT) di Kecamatan Ciampea Kabupaten Bogor" Jurnal Makna, Vol. 5, no. 1, 2014.

Kusumastuti, Retno, Eko Sakapurnama, Achmad Fauzi, Prima Nurita "Understanding Business Model of Social Innovation : Kajian Desa Wisata Bisnis Tegalwaru" Jurnal Pemikiran dan Penelitian Administrasi Bisnis dan Kewirausahaan Vol. 3, no. 4, 2018.

M. Padangaran, Ayub, Manajemen Proyek Pengembangan Masyarakat. Kendari: Unhalu Press, 2011.

Machendrawaty, Nanih dan Agus Ahmad Syafe'I , Pengembangan Masyarakat Islam. Bandung: Rosda Karya, 2001.

Mawasti, Wahanani, dan Tri Djoyo Budiono. "Memberdayakan Masyarakat Islam Melalui Bank Sampah: Strategi Komunikasi Stakeholder Bank Sampah Songolikoer." INTELEKSLA-Jurnal Pengembangan Ilmu Dakwah 1.02, 2020.

Muslim, Pertiwi, Peranan Agent of Change Pada Komunitas Masyarakat Sadar Lingkungan (My Darling) dalam Meningkatkan Kesadaran Masyarakat. Skripsi Program Studi Pendidikan Luar Sekolah Universitas Pendidikan Indonesia, 2015.

Rahmalia, Suci, Ariusni, Mike Triani "Pengarub Tingkat Pendidikan,Pengangguran,dan Kemiskinan Terbadap Kriminalitas di Indonesia" Jurnal Kajian Ekonomi dan Pembangunan Vol. 1, no. 1, 2019. 
Rukminto Adi, Isbandi, Intervensi Komunitas dan Pengembangan Masyarakat Sebagai Upaya Pemberdayaan Masyarakat. Jakarta: Rajagrafindo Persada 2008.

Sugiyono, Memahami Penelitian Kualitatif. Bandung : Alfabeta CV, 2014. Sukardi, Metodologi Penelitian Pendidikan, Kompetensi, dan Praktiknya. Yogyakarta: Bumi Aksara, 2003.

Wicaksono, Bryan. "Peran Yayasan Kreativitas Unit Usaba Muslimah (KUNTUM) Indonesia dalam Mengurangi Pengangguran Melalui Praktik Kewirausabaan Sosial di Desa Tegal Waru Ciampea - Bogor". Skripsi Program Studi Kesejahteraan Sosial, Universitas Islam Negeri Syarif Hidayatullah Jakarta, 2015.

Wiza Walady, Ahmad. "Evaluasi Program Yayasan Kuntum Indonesia Dalam Upaya Pengembangan UMKM di Kampung Wisata Bisnis Tegalwaru". Skripsi Program Studi Muamalat Ekonomi Islam Universitas Islam Negeri Syarif Hidayatullah Jakarta, 2015.

Yunita, Yuslia. "Entrepreneur Yayasan KUNTUM Indonesia dalam Pemberdayaan Ekonomi Keluarga di Desa Tegal Waru Kecamatan Ciampea Kabupaten Bogor". Skripsi Program Studi Pengembangan Masyarakat Islam Universitas Islam Negeri Syarif Hidayatullah Jakarta, 2014.

Yunus Sukmana, Ade. "Strategi Pemberdayaan Ekonomi Oleb Yayasan Kreativitas Unit Usaha Muslimah (KUNTUM) Melalui Pengembangan Usaha Kecil Menengah (UKM) di Desa Tegal Waru Ciampea Bogor". Skripsi Program Studi Kesejahteraan Sosial, Universitas Islam Negeri Syarif Hidayatullah Jakarta, 2015.

Zeid, Mestika, Metode Penelitian Kepustakaan. Jakarta : Yayasan Pustaka Obor Indonesia, 2004. 
